\begin{tabular}{ll}
\hline \hline MINING AND METALLURGY INSTITUTE BOR & ISSN: 2334-8836 (Štampano izdanje) \\
UDK: 622 & ISSN: 2406-1395 (Online) \\
\hline \hline
\end{tabular}

\title{
BENEFITS OF APPLICATION THE MODERN TECHNOLOGY OF MECHANIZED CHARGING THE BOREHOLES AT THE OP POTRLICA PLJEVLJA**
}

\begin{abstract}
In order to improve the blasting technology, the Coal Mine Pljevlja bought a vehicle for mechanized charging of boreholes. The application of this technology has significantly improved the effects and improved the conditions of blasting at the Open Pit Potrlica. The present work describes the sa-vings of application the technology of mechanized charging the boreholes. An analysis was carried out for three variants. Variant 1 involves the use of mechanized charging of boreholes with a nonel system for initiation. Variant 2 involves the use of blasting technology with cartridge explosive and Nonel initiation system. Variant 3 involves the blasting technology with detonating cord initiation.
\end{abstract}

Keywords: An-Fo explosives, blasting, mechanized charging, advancement of technology

\section{INTRODUCTION}

Coal and overburden mining at the OP Potrlica is carried out in the central and north-western part of the deposit. The mining conditions are very complex and expressed through mining - geological, mining technical and techno - economic indicators, such as:

- High dampness of deposit with the regular water inflow of around 500 $1 /$ min to $10001 / \mathrm{min}$ in the emergency situations,

- Coefficient of overburden $4 \mathrm{~cm}^{3} / \mathrm{t}$,

- Demanding physical - mechanical properties; blasting must be carried out to more than $80 \%$ of total weight,

- Proximity of building structures, infrastructure facilities, legal social land,
- The environmental impact, proximity of populated areas,

- Physical-mechanical characteristics of the work environment and possible application only a discontinuous mechanization for excavation.

Such complex mining conditions require studying and improvement the work technology in all technological operations.

The first working operation in the technological process is drilling and blasting.

In order to modernize this working operations, the coal mine Pljevlja has done the project documentation and, based on it, procured a vehicle for mechanized charging of boreholes. The vehicle has the ability to produce more types of explosives on the basis of ammonium nitrate.

\footnotetext{
* Mining and Metallurgy Institute Bor - Department Coal Engineering Belgrade e-mail: nikola.stanic@irmbor.co.rs, milan89nikolic@gmail.com

** This work is derived from the project TR37001 "The Impact of Mining Waste from RTB Bor on the Pollution of Surrounding Water Systems with the Proposal of Measures and Procedures for Reduction Harmful Effect on the Environment", funded by the Ministry of Education, Science and Technological Development of the Republic of Serbia
} 


\section{REVIEW THE CURRENT}

\section{TECHNOLOGY OF COAL}

\section{AND OVERBURDEN MINING}

Technological system of overburden mining consists of the following technological processes:

- Preparation works

- Drilling and blasting

- Excavation and loading

- Internal transport

- Overburden crushing

- Outer transport

- Disposal

Excavation is carried out with the prior blasting of overburden and coal, except in the northwestern part of the open pit where because of the proximity of town, a direct excavation is carried out. Overburden is vertically divided into floors of 15 and $10 \mathrm{~m}$, which the rope shovel excavators EKG-15, EKG 12,5, EKG 5. EKG 4.6 and EŠ6/45 operate. Transport of overburden is carried by trucks from TEREX T100 to the internal landfill or to the DTO system. DTO system consists of a crusher Krupp - Fodertehnik, hour capacity of $2400 \mathrm{t} / \mathrm{h}, 6$ belt conveyors, width $\mathrm{B}=1500 \mathrm{~mm}$ and belt spreader ARS1400/25+30.

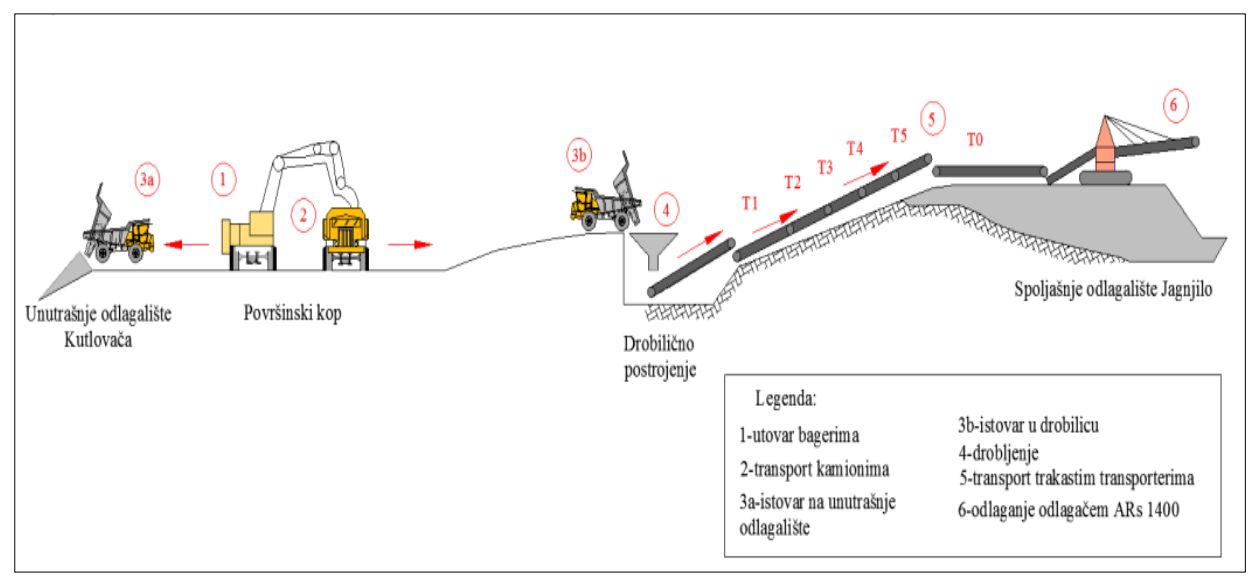

Figure 1 Technological system of over burden mining

Technological system of coal mining consists of the following technological processes:

- Preparation works

- Drilling and blasting

- Excavation and loading

- Truck transport

- Run-of-mine coal processing

The excavated coal is transported by the existing truck fleet to a plateau for coal disposal, with the exception of amount of 100.000 tons annually from the northwestern part of the OP Potrlica that is directly from the site transported to the facility for coal pre-paration and separation. The other amounts of coal, with transshipment on the plateau, are further transported to the plant for coal crushing and disposal of the TPP Pljevlja. 


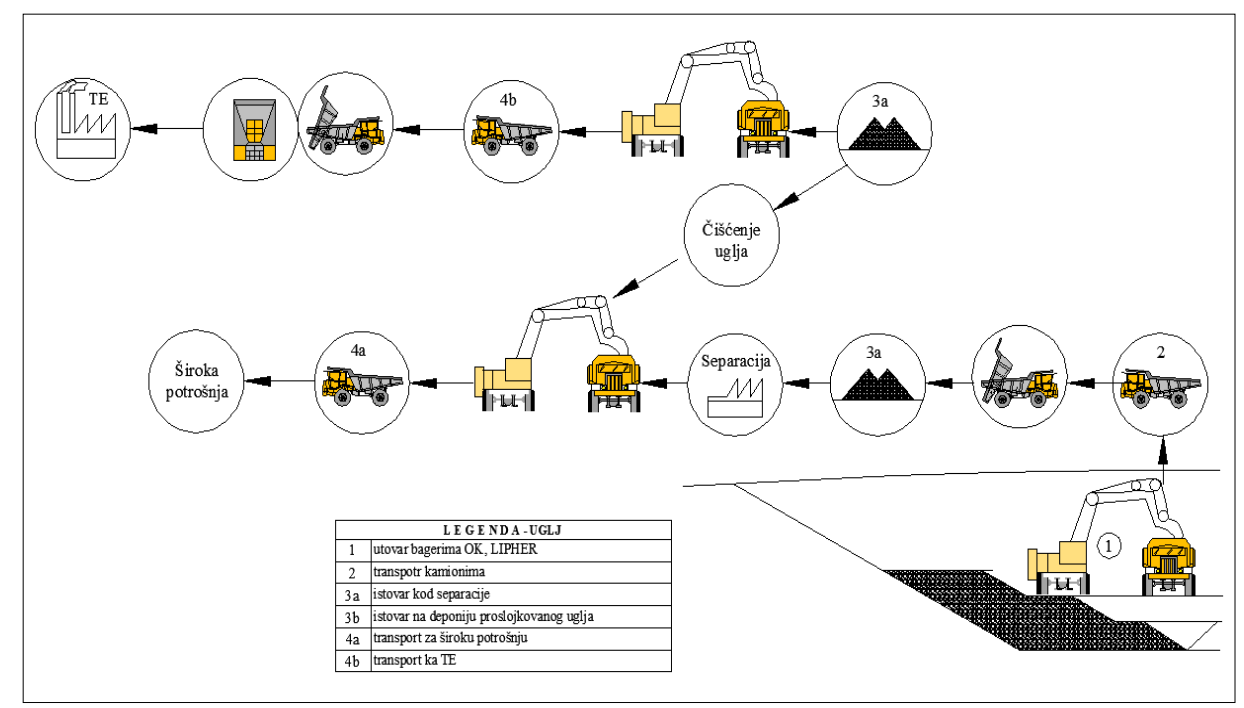

Figure 2 Technological system of coal mining

\section{PHYSICAL-MECHANICAL}

\section{CHARACTERISTICS OF THE FIELD}

Coal and overburden mining at the open pit Potrlica are carried out in the central and northwestern part of the deposit, and the mining conditions are very complex.

Physico-mechanical characteristics of the blasting working environment are listed in Table 1 and Table 2.

Table 1 Physical - mechanical characteristics of marl

\begin{tabular}{|c|c|}
\hline \multicolumn{2}{|l|}{ Marl } \\
\hline Compressive strength & $\alpha_{\mathrm{c}}=182 \mathrm{dN} / \mathrm{cm}^{2}$ \\
\hline Bulk density of marl & $\gamma=16.00-19.70 \mathrm{kN} / \mathrm{m}^{3}$ \\
\hline Bulk density of marly clay & $\gamma=23.17 \mathrm{kN} / \mathrm{m}^{3}$ \\
\hline Looseness coefficient & $\mathrm{k}_{\mathrm{r}}=1.3$ \\
\hline Propagation speed of longitudinal waves & $\mathrm{V}_{\mathrm{m}}=2.000 \mathrm{~m} / \mathrm{s}$ \\
\hline Fissure degree & II i III kategorija \\
\hline Cohesion & $\mathrm{c}_{\mathrm{sr}}=1,382.50 \mathrm{kN} / \mathrm{m}^{2}$ \\
\hline Angle of internal friction & $\mathrm{f}_{\mathrm{sr}}=28.80^{\circ}$ \\
\hline
\end{tabular}


Table 2 Physical-mechanical characteristics of coal

\begin{tabular}{|l|l|}
\hline Coal & \\
\hline Compressive strenght & $\alpha_{\mathrm{c}}=156 \mathrm{dN} / \mathrm{cm}^{2}$ \\
\hline Bulk density in natural state & $\gamma=12.30-14.80 \mathrm{kN} / \mathrm{m}^{3}$ \\
\hline Clayey thin seans between the coal seams & $\gamma=23.05 \mathrm{kN} / \mathrm{m}^{3}$ \\
\hline Underlaying clays & $\gamma=23.55 \mathrm{kN} / \mathrm{m}^{3}$ \\
\hline Looseness coefficient & $\mathrm{k}_{\mathrm{r}}=1.3$ \\
\hline Propagation speed of longitudinal waves & $\mathrm{V}_{\mathrm{m}}=1,290-1,800 \mathrm{~m} / \mathrm{s}$ \\
\hline Cohesion & $\mathrm{c}_{\mathrm{sr}}=3,100-4,800 \mathrm{kN} / \mathrm{m}^{2}$ \\
\hline Angle of internal friction & $\mathrm{f}_{\mathrm{sr}}=33^{\circ}-47^{\circ}$ \\
\hline
\end{tabular}

\section{DRILLING AND BLASTING AT THE OP POTRLICA}

\section{Review the Drilling Equipment}

Drilling of boreholes, diameter of 115 $\mathrm{mm}$, at drilling angle of $70^{\circ}$, as the slope of floor, are carried at the OP Potrlica. Length of boreholes is different depending on the height of floors or thickness of overburden and coal seam thickness.

At the OP Potrlica, taking into account the properties of the working environment, the rotary drilling system is applied.

The following hydraulic rotary drills are used for this purpose:

- BÖHLERR TCD-222

- SANDVIK Di 310

- ATLAS COPCO ROC L6-25

\section{Types of Explosives and Blasting Equipment}

At the OP Potrlica, four types of explosives are used, and the good results are achieved by thei previous applications. The An-Fo and emulsion explosives are produced in-situ in a special vehicle for production of explosives. From catridge explosives, the ammonium nitrate explosives are used of producer Poliex from Berane, as well as the cartridge waterplastic explosives, also Poliex producer. At the open pit, $80 \%$ of boreholes consist of dry boreholes, so that the An-Fo and carftridge amonium nitrate explosives have the largest use. Table 3 shows the characteristics of explosive used at the OP Potrlica.

Table 3 Characteristics of explosive used at the OP Potrlica

\begin{tabular}{|c|c|c|c|c|}
\hline \multirow[b]{2}{*}{ Characteristics } & \multicolumn{2}{|c|}{$\begin{array}{l}\text { Explosives-An-Fo } \\
\text { vehicle }\end{array}$} & \multicolumn{2}{|c|}{$\begin{array}{l}\text { CARTRIDGE } \\
\text { EXPLOSIVES }\end{array}$} \\
\hline & An-Fo & $\begin{array}{c}\text { Emulsion } \\
\text { Explosives } \\
\text { (Blendex 70/80) }\end{array}$ & $\begin{array}{l}\text { Powder } \\
\text { Explosives }\end{array}$ & $\begin{array}{l}\text { Waterplastic } \\
\text { Explosives }\end{array}$ \\
\hline Density $\left(\mathrm{kg} / \mathrm{dm}^{3}\right)$ & $0.85-0.95$ & 1.14-1.32 & $1.05-1.15$ & $1.4-1.5$ \\
\hline Detonation rate $(\mathrm{m} / \mathrm{s})$ & 3900 & 5100 & $4,100 \pm 200$ & $5,500-5,800$ \\
\hline Gustina zapr. $\left(\mathrm{kg} / \mathrm{m}^{3}\right)$ & $920-995$ & 1,010 & 940 & 1,020 \\
\hline Explosive heat (kJ/kg) & $3,661-3,800$ & $+3,000$ & 4,160 & 3,474 \\
\hline Detonation transmission $(\mathrm{cm})$ & contact & contact & contact & contact \\
\hline $\begin{array}{l}\text { Working capacity }\left(\mathrm{cm}^{3}\right) \\
\text { Trauzl equivalent test }\end{array}$ & $290-300$ & $370-455$ & $360 \pm 10$ & 400 \\
\hline
\end{tabular}


A vehicle is used at the OP Potrlica for machine charging of explosives (Figure 3 ).

It is a special vehicle TTT for production of explosives based on the mixtures of ammonium nitrate. The vehicle has a possibility to produce various types of explosives. The produced explosives can be divided into two groups:

1. The first group consists of explosives used in dry boreholes, i.e. emulsion explosives. These are explosives that have more than $60 \%$ An-Fo mixture, and the other part is the emulsion matrix.

2. The second group consists of explosives used for wet and dampness boreholes, i.e. pumped explosives. This group consists the explosives with the basis of ammonium nitrate emulsion (over 70\%) and the other part is the An-Fo mixture.

Vehicle capacity and types of explosives are shown in Table 4.

Table 4 Production capacities per types of explosives

\begin{tabular}{|c|c|c|c|c|c|c|}
\hline & \multicolumn{3}{|c|}{ Emulsion explosive } & \multicolumn{3}{c|}{ Pumped explosive } \\
\hline $\begin{array}{c}\text { Ratio emulsion } \\
\text { /An-Fo }\end{array}$ & $40 / 60$ & $30 / 70$ & An-Fo & $100 / 0$ & $80 / 20$ & $70 / 300$ \\
\hline Weight (max) & $10,400 \mathrm{~kg}$ & $12,200 \mathrm{~kg}$ & $8,600 \mathrm{~kg}$ & $4,100 \mathrm{~kg}$ & $5,200 \mathrm{~kg}$ & $5,900 \mathrm{~kg}$ \\
\hline
\end{tabular}

A vehicle chassis is Mercedes Benz, and vehicle superstructure is an American manufacturer Tradestar from Utah.
Technical characteristics of vehicle and reservoir capacity for raw materials are given in Tables 5 and 6.

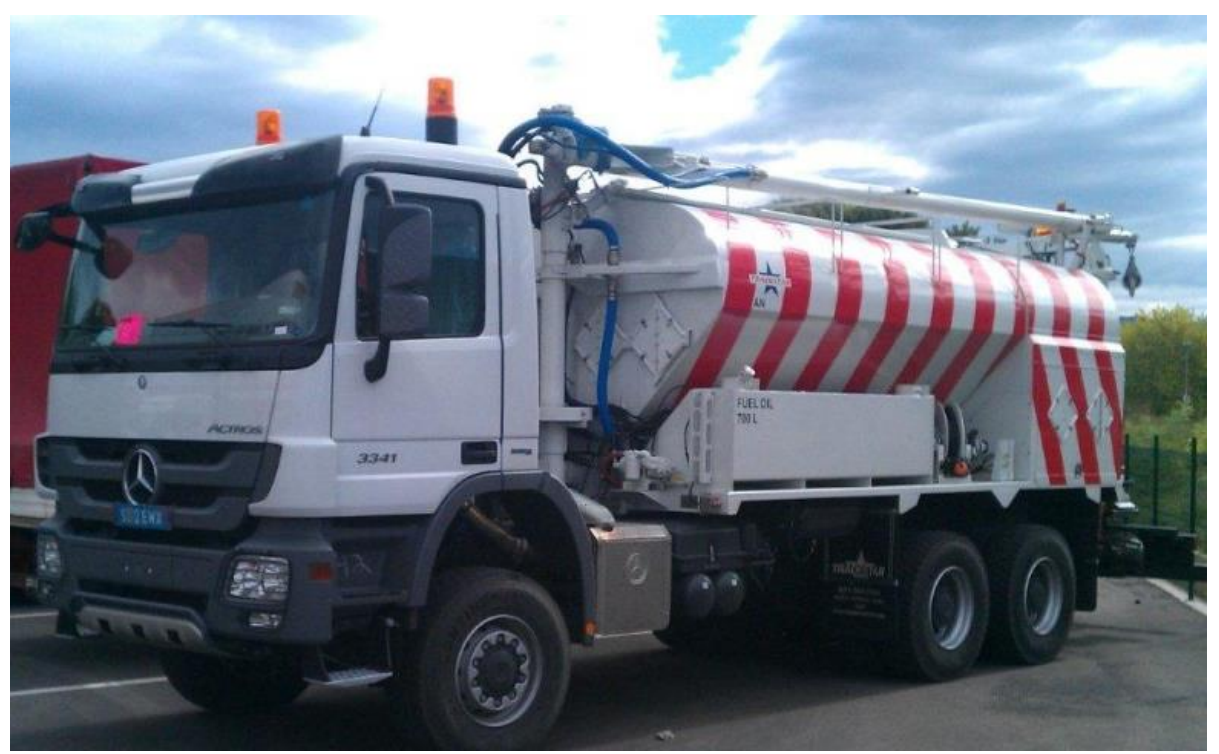

Figure 3 An-Fo vehicle for mechanized charging of boreholes 
Table 5 Technical characteristics of vehicle

\begin{tabular}{|cc|}
\hline Model & 3341 A 6x6 \\
\hline Capacity & $12 \mathrm{t}$ \\
\hline Inter-wheel base & $3600 / 3900 / 4200 / 4500 \mathrm{~mm}$ \\
\hline Engine type & V6 \\
\hline Engine power & $300 \mathrm{~kW} / 408 \mathrm{hp}$ \\
\hline Max. torque & $1850 \mathrm{Nm} / 1080 \mathrm{~min}^{-1}$ \\
\hline
\end{tabular}

Table 6 Superstructure capacity (raw materials)

\begin{tabular}{|l|c|c|c|c|}
\hline & Volume & Filled & Density & $\begin{array}{c}\text { Masses for } \\
\text { given \% filled }\end{array}$ \\
\hline Emulsion tank & Cca $3.23 \mathrm{~m}^{3}$ & $95 \%$ & $1250-1350 \mathrm{~kg} / \mathrm{m}^{3}$ & $4,140 \mathrm{~kg}$ \\
\hline AN bin & $10.34 \mathrm{~m}^{3}$ & $95 \%$ & $800 \mathrm{~kg} / \mathrm{m}^{3}$ & $8,050 \mathrm{~kg}$ \\
\hline Senzibilators/AL & $1.00 \mathrm{~m}^{3}$ & $95 \%$ & $200 \mathrm{~kg} / \mathrm{m}^{3}$ & $195 \mathrm{~kg}$ \\
\hline Diesel fuels & $700 \mathrm{~m}^{3}$ & $95 \%$ & $840 \mathrm{~kg} / \mathrm{m} 3$ & $560 \mathrm{~kg}$ \\
\hline Additive 1 & $75 \mathrm{~m}^{3}$ & $95 \%$ & $1000 \mathrm{~kg} / \mathrm{m} 3$ & $>75 \mathrm{~kg}$ \\
\hline Additive 2 & $75 \mathrm{~m}^{3}$ & $95 \%$ & $1000 \mathrm{~kg} / \mathrm{m} 3$ & $>75 \mathrm{~kg}$ \\
\hline Water & $300 \mathrm{~m}^{3}$ & $95 \%$ & $1000 \mathrm{~kg} / \mathrm{m} 3$ & $290 \mathrm{~kg}$ \\
\hline
\end{tabular}

\section{BLASTING PARAMETERS}

Since up to $80 \%$ of boreholes at the OP Potrlica are dry boreholes, the An-Fo explosives have have the largest use. A comparative use the An-Fo and cartridge ammonium nitrate explosives was analyzed.

The calculated blasting parameters are taken from the current Additional Mining Project of coal exploitation at the OP Potrlica - Pljevlja for the period 2015-2019, and are given in Table 7.

Table 7 Blasting parameters taken from the AMD DRP 2015-2019.

\begin{tabular}{|c|l|l|}
\hline & \multicolumn{1}{|c|}{ An-Fo } & Cartridge explosive \\
\hline $\mathbf{q}$ & $0.18 \mathrm{~kg} / \mathrm{m}^{3}$ & $0.107 \mathrm{~kg} / \mathrm{m}^{3}$ \\
\hline $\mathbf{p}$ & $8.82 \mathrm{~kg} / \mathrm{m}^{\prime}$ & $7.08 \mathrm{~kg} / \mathrm{m}^{\prime}$ \\
\hline $\mathbf{W}$ & $5 \mathrm{~m}$ & $5 \mathrm{~m}$ \\
\hline $\mathbf{a}$ & $5 \mathrm{~m}$ & $5 \mathrm{~m}$ \\
\hline $\mathbf{b}$ & $4.5 \mathrm{~m}$ & $4.5 \mathrm{~m}$ \\
\hline $\mathbf{Q}_{(\text {H 10) }}$ & $45 \mathrm{~kg}$ & $27 \mathrm{~kg}$ \\
\hline $\mathbf{Q}_{(\text {H 15) }}$ & $67.5 \mathrm{~kg}$ & $40 \mathrm{~kg}$ \\
\hline
\end{tabular}


The non-electric initiation system, socalled Nonel system, is used for initiation the explosive charges in boreholed. A Dual Delay System is used from many types of such initiation. Using this type of initiators, the favorable effects of blasting are achieved. Two Nonel detonators, i.e. one for the primary and one for the secondary charging, are used to initiate the blasting charge in one borehole. In explosive initiation by Nonel system, a reactive wave extends through a Nonel tube which does not damage a part of the explosive charge pillar, what is particularly important for explosives which are not sensitive to the classic initiation means. When the ANFO, "Slurry" and other insensitive explosives are initiated by detonating cord, dead pressing of explosive charges occur and its combustion in boreholes. Thereby the effect of fragmentation is reduced. A detonating cord is also used for initiation the cartridge explosives at the OP Potrlica in addition to the Nonel system.

\section{ANALYSIS OF THE DIRECT BLASTING COSTS}

\section{Consumption of Explosives and Explosive Means}

The prices of explosives and explosive means from 2016 were used for an analysis. Table 8 presents the calculated norms of consumption, which are implemented in the process of exploitation at the open pit. In addition to the norms, specified in Table 8, the unit prices of explosives are also given. The analysis was carried out for an amount of material of $5,000,000 \mathrm{~m}^{3}$, which generally corresponds to the annual production of overburden and coal with applied these types of explosives.

Table 8 Norms of consumption and unit prices

\begin{tabular}{|l|r|l|r|l|}
\hline Normative material & Norms of consumption & \multicolumn{2}{|c|}{ Unit price } \\
\hline Nonel & 0.128 & $\mathrm{~m}^{\prime} / \mathrm{m}^{3}$ & 0.23 & $€ / \mathrm{m}^{\prime}$ \\
\hline Detonating cord & 0.072 & $\mathrm{~m}^{\prime} / \mathrm{m}^{3}$ & 0.2 & $€ / \mathrm{m}^{\prime}$ \\
\hline Retarders & 0.004 & $\mathrm{kom} / \mathrm{m}^{3}$ & 1.25 & $€ / \mathrm{pcs}$. \\
\hline Safety fuse & 0.000002 & $\mathrm{~m}^{\prime} / \mathrm{m}^{3}$ & 0.2 & $€ / \mathrm{m}^{\prime}$ \\
\hline Mining lighter & 0.000002 & $\mathrm{pcs} . / \mathrm{m}^{3}$ & 0.23 & $€ /$ pcs. \\
\hline
\end{tabular}

Analysis of direct costs was carried out for three types of explosives and initiation means:

- Variant 1 - Mechanized charging of An explosives-Fo - initiation by the Nonel system

- Variant 2 - Cartridge explosives - initiation by the Nonel system

- Variant 3 - Cartridge explosives - initiation by detonating cord

Values of the specific and in annual costs of blasting are direct consequences of the calculated norms of consumption by certain variants. All relevant parameters were taken into account in calculation of norms that influence the consumption of explosive and initiation devices. First of all, those are a floor height, length of borehole, geometry of the minefield, method and diagram for connection the explosive charges within the minefield and construction of blasting charge. Taken all these factors into account, the specific costs of blasting were calculated by $\mathrm{m}^{3}$ (Figure 4 ) and annual blasting costs (Figure 5) by the analyzed variants. 


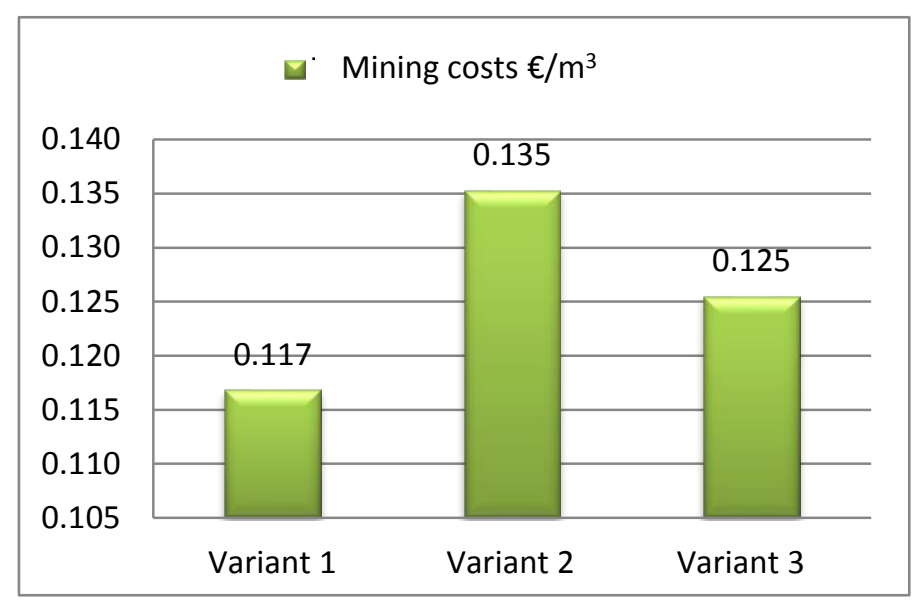

Figure 4 Specific costs of blasting for three variant in $€$ per $\mathrm{m}^{3}$

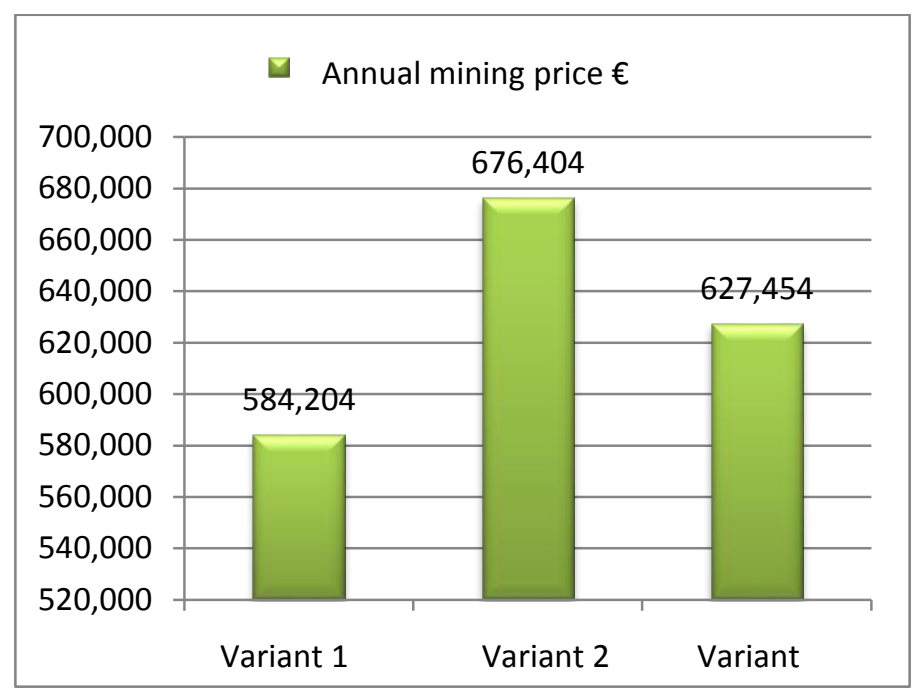

Figure 5 Annual costs of blasting for three variants given in euros

\section{LABOR FORCE ENGAGED IN \\ BLASTING}

Blasting is a complex operation in the technological process of exploitation. Therefore it is the first operation in the technological process of production, the all other technological operations are dependent on its success.

According to the current systematization in the coal mine Pljevljana, 16 workers are deployed on drilling and blasting operations, out ofwhich 10 workers are deployed on blasting. The existing systematization of jobs in blasting is done in accordance with 
the technology of blasting that was undertaken before purchasing a vehicle. By introduction the mechanized charging of boreholes, a necessary space is created for rationalization the labor force.

This primarily refers to the support workers engaged in heavy physical works (scheduling the packages of cartridge explo sives across a minefield, etc.). It is not necessary in mechanized charging of boreholes because a complete transport of explosives from the storage to the incorpo-ration into the borehole is carried out by An-Fo vehicle. Table 9 presents the existing systematization of jobs with the number of employees and the level of income on blasting jobs.

Table 9 Systematization of jobs on blasting

\begin{tabular}{|l|l|c|c|c|c|}
\hline \multicolumn{1}{|c|}{$\begin{array}{c}\text { Job position of } \\
\text { employee }\end{array}$} & \multicolumn{1}{|c|}{$\begin{array}{c}\text { Profess. } \\
\text { clasif. }\end{array}$} & $\begin{array}{c}\text { No. of em- } \\
\text { ployee }\end{array}$ & $\begin{array}{c}\text { Gross monthly } \\
\text { wage of } \\
\text { employees }\end{array}$ & Total & $\begin{array}{c}\text { Gross } \\
\text { annual } \\
\text { wage }\end{array}$ \\
\hline $\begin{array}{l}\text { Chief engineer for } \\
\text { drilling and blasting }\end{array}$ & $\begin{array}{l}\text { Univer. } \\
\text { degree }\end{array}$ & 1 & 1,530 & 1,530 & 18,360 \\
\hline $\begin{array}{l}\text { Foreman for drilling } \\
\text { and blasting }\end{array}$ & $\begin{array}{l}\text { High school } \\
\text { ed. }\end{array}$ & 1 & 1,190 & 1,190 & 14,280 \\
\hline $\begin{array}{l}\text { High school } \\
\text { Igniter of blasts }\end{array}$ & 2 & 1,105 & 2,210 & 26,520 \\
\hline $\begin{array}{l}\text { ed. } \\
\text { Driver of vehicle for } \\
\text { explosive }\end{array}$ & $\begin{array}{l}\text { Highly quali- } \\
\text { fied worker }\end{array}$ & 1 & 1,020 & 1,020 & 12,240 \\
\hline $\begin{array}{l}\text { Operator of vehicle } \\
\text { for An-Fo explosives }\end{array}$ & $\begin{array}{l}\text { Highly } \\
\text { qualified } \\
\text { worker }\end{array}$ & 1 & 1,020 & 1,020 & 12,240 \\
\hline \begin{tabular}{llll|} 
Assistant of igniter \\
of blasts
\end{tabular} & $\begin{array}{l}\text { Unqualif. } \\
\text { worker }\end{array}$ & 4 & 850 & 3400 & 40,800 \\
\hline
\end{tabular}

After the analysis of three variants of blasting, the cost savings were calculated in implementation the mechanized method of blasting with explosives An-Fo (Variant 1), and they are shown in Table 10. The savings are given in relation to the blasting technology with cartridge explosives when the initiation is performed by the Nonel system (Variant 2), and when the initiation is performed by a detonating cord (Variant 3 ).

Table 10 Blasting costs per analyzed variants and savings in introduction the mechanized method of charging the boreholes

\begin{tabular}{l|c|c|c}
\hline & Variant 1 & Variant 2 & Variant 3 \\
\hline Blasting costs & $0.117 € / \mathrm{m}^{3}$ & $0.135 € / \mathrm{m}^{3}$ & $0.125 € / \mathrm{m}^{3}$ \\
\hline Annual price of blasting & $584,204 €$ & $676,404 €$ & $627,454 €$ \\
\hline Labor costs & $86,700 €$ & $131,580 €$ & $131,580 €$ \\
\hline Total & $670,904 €$ & $807,984 €$ & $759,034 €$ \\
\hline \hline Savings by introduction of & $/$ & $137,080 €$ & $88,130 €$ \\
\hline mechanized charging & $/$ & $17 \%$ & $12 \%$ \\
\hline
\end{tabular}


It is seen in Table 10 that the annual savings in Variant 1 as compared to Variant 22 , is $€ 137.080$, and $17 \%$ respectively, and the savings with respect to Variant $3,88,130 €$ or $12 \%$ compared to total costs of blasting according to Variant 1.

\section{CONCLUSION}

In addition to the benefits of application the mechanized charging relating to the direct cost savings that have been presented in the paper, there are also the indirect cost savings. Applying the An-Fo explosives achieve better results in blasting (better material granulation) what directly affects the other technological processes.

Granulation of blasted materials directly affects the process of excavation and loading, as well as the technological process of crushing, which is expressed by a higher energy efficiency. The direct impact of blas- ting effects is also on the extent of engagement the auxiliary mechanization.

The use of mechanized charging the boreholes enables more economical, safer, more efficient and easier operation in performing the technological process of blasting.

\section{REFERENCES}

[1] Additional Mining Project of Coal Mining at the Open Pit "Potrlica" Pljevlja for the Period 2015 - 2019 (in Serbian)

[2] Simplified Mining Project on Overburden Drilling and Blasting at the Open Pit "Potrlica" - Plevlja 2013(in Serbian)

[3] Purtić N., Drilling and Blasting, 1991, Faculty of Mining and Geology, Belgrade (in Serbian)

[4] Savić M., Blasting at the Open Pits (in Serbian) 